\title{
THE FIRST LIBERAL-RADICAL COALITION GOVERNMENT IN THE KINGDOM OF SERBIA IN 1887
}

\author{
UDC 323(497.11)"1887"
}

\author{
Miroslav Pešić \\ University of Niš, Faculty of Philosophy, Department of History, Serbia
}

\begin{abstract}
This paper deals with the liberal-radical government in the Kingdom of Serbia from 1887. This was the first coalition government in the history of the modernday Serbian state, which consisted of liberals and radicals. In order to come to power, the Radicals agreed to fewer current sectors, while the ministries of foreign and internal affairs joined the liberals. The most important points of the government program, which reflected a mutual compromise, concerned the improvement of relations with Russia in foreign and changes in the Constitution in internal politics.
\end{abstract}

Key words: Jovan Ristic, national assembly, government, liberals, constitution, radicals.

After the Serbian-Bulgarian War of $1885,{ }^{1}$ the inner political life in the Kingdom of Serbia was very tense. There were internal disagreements, both at court and in the parties. King Milan did not want to see radicals at the head of the country, but without them no government could be stable (Krestić i Ljušić 1991, 155). The most prominent members of the Radical Party held a conference in Nis on February 18, 1886, in which the cooperation between the radicals and progressives should have been discussed. Only Pera Todorovic pleaded for an alliance, pointing out to the members that the King was ready to entrust the Radicals with the Progressives in an alliance with the Radicals. After the Radicals rejected the agreement, King Milan re-appointed the government with the composition of the government to the Progressives. On April 18, 1886, representatives of the Belgrade Radicals and Liberals reached an agreement on the common political activity on the religious holiday Cveti, or Palm Sunday. In addition to the amendment of the Constitution in the field of internal politics, the agreement envisaged the raising of the country's economic and production potential, as well as the implementation of an educational reform and the organization of state finances. When it comes to foreign policy, both sides agreed

Received March 30, 2018 / Accepted October 14, 2018

Corresponding author: Miroslav Pešić

University of Niš, Faculty of Philosophy, Ćirila i Metodija 2, 18000 Niš, Serbia

E-mail: miroslav.pesic@ filfak.ni.ac.rs

${ }^{1}$ All dates in the text are given by the new calendar, unless otherwise stated. 
on the establishment of good relations with the great powers, especially with the Balkan states. The agreement was supported by the entire Liberal Party, but not by the entire Radical Party, but only by a group of Belgrade radicals. Radical Raša Milošević expressed his opposition to the agreement with the Liberals in writing, after giving a separate opinion (Pešić 2017, 183-184). The efforts of prominent Radicals Stojan Protić and Jovan Čaja to gain rediscovery from the interior of the country for the agreement did not come to fruition. After the parliamentary elections in the summer of 1886, the Club of Radical MPs was formed, which began reorganizing the party. In October they approved a liberal-radical agreement and excluded Pera Todorovic from the party. In this way, the unity of the party has been preserved and the cleft "which was at the very top" has been prevented. The agreement was good for both sides. The Liberals agreed to a constitutional reform, while the radicals could come to power only in coalition with them. The joint forces were given the mandate to form the first coalition government led by Jovan Ristic as president and foreign minister on June 13, 1887 (Krestic i Ljušić 1991, 156).

After the fall of the Garašanin Government, on June 13, 1887, the Radical Liberal Government was formed. The key government departments were the leading political figures of the Liberal and Radical Party. Jovan Ristic became the Prime Minister and Minister of Foreign Affairs, Radivoje Milojković the Minister of the Interior, Jovan Đ. Avakumović the Minister of Justice, Mihailo V. Vujić the Minister of Finance, Alimpija Vasiljević the Minister of Education and Ecclesiastical Affairs, Anta M. Bogićević the Minister of Defense until July 17, followed by Sava Grujić, Minister of Construction Pera Velimirović and Minister of National Economy Svetozar Milosavljević (Ljušić 2005, 154). In the history of modern-day Serbia, this was the first coalition government (Ljušić 2005, 153; AS, RO, k.VI, No. 67). According to the coalition agreement, government departments were equally distributed between Liberals and Radicals, with politically influential ministries taken over by the liberals. In all likelihood, this could be expected, because for the first time in the history of the Radical Party its representatives were in power (Radenić 1988, 865). Regardless of the fact that the two most important ministries of foreign and internal affairs belonged to the liberals, Nikola Pašić in a letter to Kosta Taušanović told radical leaders that with the Liberal Party ministers "they must live in a continuous agreement, they must always move within the bounds of the established agreement, and everything that lies outside this agreement, and came to the solution, should be settled by agreement or postponed for later periods if there is no spending on state affairs" (Mitrović 1971, 121; Perović i Šemjakin, 1995, 257).

The new government was greeted with great enthusiasm by wide masses. Slobodan Jovanović says that the capital was "overwhelmed" with local party champions who came to congratulate their ministers on coming to power. In these celebrations which "Odjek" called "the magnificent folk odyssey", a great number of progressives were killed. The beating of the progressives was not encouraged, but was not suppressed either (Jovanović 1990, 320-321). Ristić submitted a program of the future radical-liberal government to King Milan for approval. The main points of the program were: improvement of relations with Russia, reduction of state expenditures, reduction of overcrowded state administration, prohibition of further borrowing "for both the state and the municipalities that also took the road dangerous for the economic development of the country" and the adoption of the new Constitution in a free spirit. The King signed the program of the future government, under the condition that the issue of the return of the deposed Metropolitan Mihailo to "his civic duty" be postponed until August 1887 (Živanović 1924, 328-329). A constitutional reform had a special place in the 
coalition government program, one that would replace the Constitution of 1869 with a Constitution "which would contain more complete constitutional guarantees in every respect." The constitutional review program envisioned the creation of a "Committee of Representatives of All Political Thoughts" to draft the Constitution and to submit it for approval to the King. ${ }^{2}$ Milan Đ. Milićević alleges that Jovan Ristić asked Milan Piroćanac to select five prominent representatives of the Progressive Party for the Constitutional Committee "just not those who have been expelled" (ASANU, No. 9327, Milan Milicevic's Journal, July 27, 1887, Vol. XIII, 2087).

The draft of the constitution drafted by the Constitutional Committee contained 133 members, divided into fourteen chapters. According to the Constitution draft, Serbia is defined as a constitutional monarchy with the People's Representation (Article 1). Legislative authority under this Constitution draft was performed by the King and the oneminded People's Representation. The National Assembly was made from freely elected deputies and deputies in position. Each district was elected by a single deputy at 3,000 tax heads. The town of Belgrade elected one deputy per 3,000 taxpayers. MPs by position had the same rights as elected MPs. Members of the National Council, the members of the State Council, generals in the active service, the President of the Court of Cassation, the President of the Main Control Board, the President of the Belgrade Municipality, the Rector of the Grand School, the Governor of the National Bank and the Loan Manager entered the National Assembly. Every adult citizen who paid at least 15 dinars of direct tax had the right to vote. Every Serbian citizen who turned 30 and paid the state 30 dinars of direct tax annually could be nominated for a deputy. Only police officers could not be elected as deputies. The National Assembly met regularly every year in Belgrade on November 15, while the King was entitled to convene an extraordinary session. This constitutional draft, unlike the Constitution of 1869, stipulates that the Assembly itself elects the Presidency, that is, President, Vice-Presidents and Secretaries. For the full work of the Assembly, a quorum of two-thirds of the deputies was required. In the exercise of legislative power, the Assembly has become more important than the King. "No law can be issued, abolished, amended or interpreted without the consent of the National Assembly" (Art. 74). The Constitution draft provided for the political responsibility of ministers. "The National Assembly has the right to charge ministers, if they commit treason against the state or the government, if by part or non-negligence, with knowledge or negligence, they violate the Constitution or recognized constitutional rights of citizens, if their actions bring the security of the state in danger or if they damage the state of goodness" (Art. 84). The ministers were tried by a special court composed of members of the State Council and the Court of Cassation. Without the approval of the National Assembly, the King did not have the right to pardon a convicted minister (ASANU, JR, IV/3, No. 33-34).

\footnotetext{
2 The Constitutional Committee consisted of: Giga Gersic, Professor of the Grand School, Dimitrije Radovic, President of the Court of Cassation, Djordje Cenić, President of the State Council, Đ. S. Simic is a graduate agent at his disposal, Djordje Pavlovic, a deputy in Rome, Jovan Belimarkovic, retired general, Jovan Avakumovic, justice minister, Kosta Protic, retired general, Kosta Tausanovic, director of the Aid for Support and Savings, Ljubomir Kaljevic, deputy in Athens, Milan Bogicevic deputy in Vienna, Mihailo Kr. Đorđević Public Attorney, Milan Đ. Milicevic, library librarian, Pavle Mihailovic, former secretary of the ministry, Stojan Boskovic, member of the State Council, and Stojan Markovic, professor of the Grand School (Zivanovic 1924, 330-331).
} 
Soon after the formation of the Constitutional Committee, the Progressive Assembly was dissolved and new elections were called for September 29, 1887. Although allies, radicals and liberals went to the polls separately, while intimidated progressives "did not even participate." Since the Progressives did not participate in the election race, a fierce political struggle was waged between the "remaining two parties" (Kovačević 2003, 328329). Conflicts between the Radicals and the Liberals began in the division of rank-andfile positions.

Raša Milošević described that situation in the following manner:

\begin{abstract}
"Immediately in the very beginning of political life, according to the agreement, there was a lack of political connection in the government; the division of power has broken in this marriage. Radivoje Milojković /.../ was reluctant to see that his comrades in the cabinet, his pupils in the state administration made complaints, and even less he could suffer to interfere with his affairs. Even the division of the district's chief positions was not favorably received by the radicals, who were outside the ministry. Using radicals that do not have enough people ready, Radivoje had enough reasons to set up his tried police force for the district chiefs" (Milošević 1923, 243; Stojičić 1980, 228).
\end{abstract}

For radicals it was important to preserve the power in the Assembly because they were aware that the parliamentary majority allowed them a greater degree of influence on the conduct of state affairs. Stojan Protic said that "the big question is who will have the majority in the new National Assembly. The Radicals should not allow themselves to remain in the minority, as the majority gave them the only possibility that they could have serious influence on the administration of the country, both in the government and in the National Assembly. All the administration, the State Council, the courts were made up of the elements of the opposite radicals. The elections were new, they were the new trial stone for the maintenance of the coalition." (Protić 1912, 91-92; Stojičić 1980, 229)

In the elections of September 29, 1887, the Radicals won 87, and the Liberals won 59 seats, which meant that the majority in the Assembly depended on the government deputies appointed by the King. The liberals were surprised by the results of the election, because they could not believe that radicals would win 30 places more than them (Jovanović, 1990, 322). Despite pressure from the police, the Liberals suffered a heavy defeat in the elections. ${ }^{3}$ In order to establish the balance of power in the Assembly, Ristic demanded that 52 government MPs be liberated and 12 radicals, while the radicals insisted on respecting electoral results, i.e. that mandates should be aligned equally. In accordance with his authority, King Milan granted 36 Liberals to the Radicals of 16 seats. Although the King did not fully comply with the demands of the liberals, he nevertheless reduced the numerical advantage of the Radical deputies, with the possibility of liberating them in additional elections "for the 10 remaining seats" (Radenić 1988, 866). Encouraging conflict between the coalition partners, King Milan intended to make both sides "dependent on himself and his will, and ultimately carry out what he wanted" (Kazimirović 1990, 487). In conversations with representatives of the Liberals, he protested against the Radicals, while he spoke to the leaders of the Radical Party against

\footnotetext{
${ }^{3}$ Milan Piroćanac states that "liberals along with all means scarred by the authorities and the enforced violence / ... / still were the minorities in the elections. And if the police were not in their hands, they would not get more than 10 seats in the whole country, that's for sure" (Piroćanac 2005, 394).
} 
the Liberals. At the end of September 1887, King Milan sent a letter to Jovan Ristić, stating that he would not take any radical as a government deputy "even if a partial ministerial crisis was created". In this letter, on October 10, 1887, King Milan said to Ristic that he had no intention of making any concessions to the radicals, which would be against the interests of the Liberal Party. He further stated that the radicals behave like "little children", insisting on the demands for the adoption of the Constitution, according to the provisions of their draft and the change of foreign policy in the direction of intensifying relations with the Austro-Hungarian Empire. Less than three months later, the mandate for the composition of the independent government was entrusted to the radicals (Živanović 1924, 335; Radenić 1988, 867).

In his newspaper "Radikal"4, Pera Todorović criticized the leadership of the Radical Party for giving the majority in the Assembly to the Liberals. Todorovic called on Radical MPs to persevere in their belief that the liberals would not allow any place more than radicals (Radikal, No. 6, 25 October / 6 November 1887). In a letter to Milutin Garašanin of August 6, 1887, Pera Todorović stated that the alliance between the Radicals and the Liberals was "very ill" and refused to join the "patient" because it would soon turn out "that I would publicly come out against this scandal of the Radical Party". In this letter, Pera Todorović stressed that "he had not had darker and tougher days in his life" and that "what tortured him the most and hurt him the hardest" was the lack of sincerity he was repaid with . "Being at the immediate intersection, doubting, unbelieving - it is worse than being crucified on a cross." (Todorović 2000, 207-208).

The National Assembly met in Belgrade on November 27, 1887 for its regular session in 1887. At the assembly session of December 3, 1887, the candidates for the Presidency of the Assembly were elected. Dimitrije Katić won 195 votes, Kosta Taušanović 194, Todor Tucaković 193, Pavle Vuković 191, Ak. Nikolajević185, Stojan Bošković 9, Rista Popović 7, Sima Nestorović and Arsa Drenovac one vote. Prime Minister Jovan Ristić handed the Royal Decree over to the provisional Assembly President Milovan Spasić, appointing Todor Tucaković President of the Assembly, and Pavle Vuković Vice President. The secretaries were elected: Ilija Stošić, Miloje Vlajić, Živko Sedlarac, Ljuba Novaković, Milovan Milovanovćc and Paštrović (Radikal, No. 16, November 23 / December 5, 1887). Todorović made use of the choice of Liberal Todor Tucaković as the president of the Assembly to attack the radical champions again because of the feasible policy towards the liberals. He called on Radical MPs from the interior to suppress party champions from Belgrade (Radikal, No. 17, November 25 / December 7, 1887).

The assembly was opened with a Throne sermon on December 4, 1887. In that sermon the King urged the deputies to pay special attention to arranging the difficult financial situation in the country. Furthermore, the need for replacing the Constitution of 1869 which was adopted in "the hardest conditions that one country can encounter" was replaced with a new Constitution, because "as the bad times started to disappear and the country developed and advanced, the need arose that the earthly constitution should be examined and enhanced by the acquired experience" (Radikal, No. 16, 23 November / 5 December 1887). At its first regular session on December 7, 1887, the Assembly elected the members of the Legislative, Financial, Complaints and Appeals Committee and

\footnotetext{
${ }^{4}$ In October 1887, Pera Todorović launched the "Radikal" newspaper, in which he fought against a radicalliberal government.
} 
Address Board. Stojan Bošković, Gliša Geršić, Stojan Ribarac, Dimitrije Katić, Ars Drenovac, Kole Rašić, Andrej Nikolić, Stojan Protić, Živojin Veličković, Pera Đorđević, Mika Đorđević, Živan Živanović, Priest Novak Milošević, Aksentije Kovačević, Jovan Bošković and Milan Andonović were elected to the Address Board (Radikal, No. 17, November 25 / December 7, 1887). When drafting a parliamentary address, the representatives of the joint Radical Liberal Club first declared that the address of the assembly should not be an ordinary paraphrase of the throne sermon, but it should also contain the wishes of the people. However, King Milan told the members of the Address Board that the content of the address was unacceptable to him because it is in opposition to the Throne sermon. Therefore, the address "must be a simple greeting" of the Throne sermon (Radikal, No. 18, November 27 / December 9, 1887). To the members of the Address Board Ristic said: "Since the King does not want to receive such an address, the Ministry will step down and the King will certainly call N. Hristić, or Garašanin. The committee agreed that they should delete everything from the address, which was not a simple paraphrase of the Throne sermon." On December 10, 1887, the Assembly adopted an address that was an ordinary paraphrase of the sermon. Regarding the address, King Milan stated in the Assembly that its main task is to adopt financial laws and nothing more than that and "that it is not in a position to give him direction in politics. For the requested freedoms, he said that there are enough of them, that they do not see that there is no honest man in Serbia according to this Law on the Press" (Piroćanac 2005, 403-405).

In the supplementary elections in those polling stations where the elections from September 29 were annulled due to established irregularities, the liberals sought to win as many parliamentary seats as possible in order to reach an equal number as the radicals in the Assembly. Due to the pressure of the police, in the subsequent elections of December 23,1887 , the liberal candidates were elected at all ten polling stations. Two days after the elections the article Subsequent Elections came out in "Odjek", in which the Radicals strongly attacked Interior Minister Radivoje Milojković because of police interference in the election process (Odjek, No. 130, December 13, 25, 1887). The Radicals disputed the regularity of the subsequent elections and demanded the removal of Interior Minister Radivoje Milojković and the annulment of the disputed elections. Unlike his deputy club, Ristic was ready to sacrifice Radivoje Milojković in the interest of preserving the coalition government, as he also sacrificed the Metropolitan Mihailo. "In politics, there is no marriage for life", said Ristic (Jovanovic 1990, 327). However, Ristic's proposal to sacrifice Radivoje Milojković was not enough to King Milan, who said that secularism between coalition partners "weakens the government" and that such a government cannot survive. Remaining without the King's support, Ristić resigned on December 29, 1887. After the resignation of the coalition government, King Milan first talked about the composition of the new government with the Progressives, but soon gave up on that intention because in that case "it was necessary to dissolve" the Assembly in which the Radicals had the majority and scheduled new elections. Pressed by the Austro-Hungarian MP, King Milan changed his decision and began negotiating with the Radicals. During these negotiations, the King set two conditions for the Radicals: to give Pero Todorović a ministerial post in the future government and to leave the administration of the country's foreign policy to the King, that is, to get the right to appoint his man as the Minister of Foreign Affairs. (Kovačević 2003, 336-337).

The representatives of the Radical Party submitted a program of the future Radical Government to King Milan, which was drafted by the Radical Assembly Club on December 
30, 1887. This program included the following points: the change of the Municipal Law "on the principle of self-government", the amendment of the Electoral Law in the direction of "greater precision of the citizens' right to vote, the adoption of the Press Law, which would not be stricter than "the criminal law itself", the change of the Law on Choirs and associations, the reform of the Law on Judges in terms of greater judicial independence. In terms of finance, the Radical Assembly Club proposed the conclusion of a loan for the payment of temporary state debt. When it comes to foreign policy, the radicals agreed that the foreign ministry would be in the hands of a "purely royal man", with the minister of foreign affairs who besides enjoying the trust of the King "should still enjoy the confidence of the radical assembly club". In line with the royal demands the Radical Assembly Club stated in relation to the church question "that the issue does not enter the program of the new government and the People's Representation". Some indulgence of radicals was also shown in the question of "the amnesty of political criminals from 1883", respecting the king's constitutional right to pardon. Thus, the amnesty of the radical refugees during the Timok rebellion was completely left to King Milan. Regarding the constitutional reform, they stated that, in agreement with King Milan, the amendment to the Constitution would be "after the end of the legitimate legislative tasks in this session of the National Representation" (Protić 1912, 104-113; Radenić 1988, 873-874; Krestić i Ljušić, 1991 161-164).

The first pure radical government in the history of the Radical Party was formed on December 31, 1887. Sava Grujić became Prime Minister and Minister of the Army, Dragutin Franasović the Minister of Foreign Affairs, a man who was trusted by King Milan, Svetozar Milosavljević the Interior Minister, Giga Geršić the Justice Minister, Mihailo Vujić the Minister of Finance, Giga Geršic the Representative of the Ministry of Education and Church Affairs, Pera Velimirović the Minister of Construction and Stevan Popović the Minister of National Economy (Ljušić, 2005, 156). In accordance with the agreement reached, King Milan informed the Prime Minister Colonel Sava Grujić, in a letter dated January 3, 1888, that he had made the decision to allow free emigrants to return to the country, except for Nikola Pašić. Nikola Pašić was not even pardoned this time "because of the treacherous preparations against the fatherland and Serbian thought in the autumn of 1885 " (Odjek, br.1, 01/13 January 1888). Due to the resignation of the coalition government, a break in the work of the National Assembly took place, which lasted until January 2, 1888. In the Assembly, Prime Minister Sava Grujic presented the work program of the future government (Radenic 1988, 876). The government promised to enact the Law on Municipalities, change the Press Act, public chambers and associations. In terms of finance, the Government pledged "to save savings in all branches of the state administration. In order to achieve this, the government will strive to simplify the administration, and in the same way to properly charge the state, the government hopes to achieve a balance in the state budget over time". When it comes to constitutional reform, the need for accession to change the Constitution, i.e. that the Government will, as soon as the Government receives the permission of the King, present the draft Constitution before the Constitutional Assembly. In foreign policy, the government will maintain good relations with all great powers "on the basis of respect for mutual interests, and in particular we will be pleased to deserve the impasse of the forces that have worked and are working on self-preservation and the free development of peoples in the European East" (1887 National Assembly Stenographic Notes Belgrade, 1888, 983-984). At the parliamentary session of January 2, 1888, the new Government submitted to the Assembly a proposal for the Law on the conclusion of a new loan. At that time, the Kingdom of Serbia owed 254.1 million dinars to its creditors, while 
the temporary (flying) debt amounted to 32.1 million dinars. In order to regulate state finances, the Radical Government of Sava Grujić asked the Assembly to approve a new loan. On January 12, 1888, the Assembly adopted a law authorizing the conclusion of a new loan. A new loan for treating finance and liquidating temporary debts was concluded in January 1888 with Escont Service Contracts, Lenderbank and the Berlin Trade Association, "the same banks with which the progressives had worked". The amount of the loan amounted to 21 million dinars, while the Serbian state guaranteed its repayment with a trade tax of 1.65 million dinars, which was collected in a special cash register (Kovačević 2003, 340). A few days later, on January 23, 1888, the King's order to dissolve the Assembly followed, while new elections were scheduled for March 5, 1888 (Zivanovic 1924, 357).

At the elections, the Radicals were convincingly defeated by the Liberals. Of the 156 elected MPs, the Radicals won 133, Liberals 15, while the Progressives boycotted the elections. The seven newly elected MPs were announced to be "of unknown party affiliations". The elections were canceled at one polling station in Vranje (Radenić 1988, 878). By the order of King Milan, the regular convening of the National Assembly for 1887 began on March 31, 1887 (Srpske novine, No. 64, 20 March / 1 April 1888). Rista Popović was appointed president of the Assembly, and Paja Vuković was appointed Vice President. The Assembly elected Milovan Marinković, Ljubo Novaković, Pero Đorđević, Đuro Milijasevic, Kosta Borisavljević, Ljubo Joksimović and Aleks Radojević for the secretaries (Mitrinović i Brašić 1937, 105). Assembly sessions were opened on April 2, 1888 by the reading of the Royal Decree on his confidence in the Government. For the first time in the history of Serbian parliamentarism, the Assembly was opened without the King's opening statement. The King did not appear at the Assembly. At a reception held in court, he made it clear to the representatives of the government that he was dissatisfied with the behavior of certain radicals, radical representatives and the media (Živanović 1924, 363).

In accordance with the aforementioned program from 1887, at the beginning of the Assembly session on March 31, 1888, the Government proposed to the Parliament two most important political laws: the Law on Municipalities and the Law on Amendments to the Law on Choirs and Associations. In the draft of the law on municipalities, they were defined as "basic political and administrative units" that are "self-manageable in their municipal affairs, and as parts of the state and enforcers of the laws of the territorial or legal orders of the state authorities, are subject to the general earthly laws and supervision of the state administration according to the provisions of this Law" (Art. 1). Another article of the Law on Municipalities caused a sharp controversy in the Assembly. The majority in the Legislative Committee advocated for larger municipalities, i.e. that municipalities cannot have less than 300 tax heads, while the minority of the municipality considered that municipalities could have 200 tax heads. The majority members stressed that small municipalities are economically unprofitable and cannot survive as such (Novak Milošević, Ranko Tajsić). Defending the positions of the communist minority Petar Maksimović, a radical deputy from Smederevo said that "when the municipality" was not financially strong with 500 tax heads according to the progressives' Municipal Law of 1884, then there would be no "strong financial strength" with 300, 200 tax heads. In the opinion of members of the committee minority, it was necessary to create as many small municipalities as possible so that the people would be settled in those other needs and requirements, that is, they would be facilitated by the judiciary, which was increased in the municipal courts, and people from the villages would not have to go to other villages to be heard by a judge, and would quickly and easily come to justice. "The parliamentary debate has been so prolonged" 
that many deputies began to shout from their places: "Let's resolve the matter, there has been too much talk." During the vote, 88 MPs voted for a proposal for a committee minority, while the majority of the proposal was supported by 83 MPs. The amount of the electoral censorship for acquiring electoral rights at the municipal assembly caused a fierce discussion in the Assembly. The government proposed a voting census of 15 dinars of direct tax annually. The majority in the Legislative Committee proposed the change of the electoral censuses "so that the municipal assembly has the right to vote all adult members of the municipality who pay for as much as in the name of direct tax, and which are not under tutelage". The Minister of Internal Affairs rejected the proposal of the majority and proposed to "dismiss the 10 dinars." In defense of the proposal of the committee majority, Ranko Tajsić pointed out that "even under the Turks, everyone was free to vote in the choice of serfs. When they allowed our elders to choose the serfs, they did not interfere, nor did they say: this one has the right to vote, and this one does not, but every citizen who lived on their brief had the right to vote for his serf." Members who defended the introduction of a censorship said "without it there will be people (poor) who will sell their beliefs". Most of the deputies supported the proposal of the Minister of Internal Affairs, Svetozar Milosavljević, to introduce an election census of 10 dinars of direct tax annually for the acquisition of voting rights (Dukić 2008, 73-78). According to the radical proposal of the Law on Municipalities, the freedom of choice of municipal authorities was ensured in such a way that the police authority "could not in any way interfere with the election and for which reason the day of the election was postponed" (Art. 30). The control of state authority over the work of municipal authorities is regulated in such a way that the supervisory authority could keep from executing that decision of the municipal authorities that would be contrary to the state's legislation. Against the decisions of the state authorities, municipal authorities could appeal to the Minister of Internal Affairs, whose decision was final. The state authorities were not allowed to punish and dismiss the municipal authorities, but they could have, at the expense of the president of the court, farmers or agricultural assistants to execute those legal orders that they would not want to execute. The supervisory state power could only suggest to the municipal assembly that some municipal officials who did not want to execute statutory orders would be ousted from power. The Minister was obliged to issue a decision on the guilt of the municipal authorities within twenty days. to be responsible, depending on the severity of the punishment, "by loss of three-months salary in favor of a municipal cash register or dismissal from office" (Art. 81) (AS, NS, F6-348 / 88).

The Radical Government of Sava Grujic envisaged the division of the army into an active (standing) and national by the proposal of the Law on Amendments to the Law on the Organization of the Army adopted on April 3, 1888. This law represented a combination of a national and standing army, with the first call still being regulated as a standing army, and the second and third calls would represent the national army (Jovanović 1990, 332). The new Law on Choirs and Radicals' Associations intended to bring into force the Law of 1881, i.e. to amend the Law on Associations, which the Progressives brought after the Timok Rebellion on June 23, 1884 (Janković 1997, 389). However, the proposed Laws brought great resentment with King Milan, who told the Austro-Hungarian deputy Hengelmiler that "the Radical Party is working on the preparation of the revolution and that they only wants to get it on time, so that they could pass the Law on the formation of a national army, and on the basis of it arm the people and then start the revolution". After the conversation, it was clear to the Austro-Hungarian MP that King Milan "was looking for a reason for the break with the present government, which could perhaps have been found 
already at the earliest time when the Law on Municipalities was already on the agenda" (Kovačević 2003, 346). The king was increasingly showing disappointment the Radicals and sought a way to overthrow the Radical Government. ${ }^{5}$ When the Radical Government submitted the signed Law on Municipalities to the King, adopted in the Assembly by a large majority, he refused to sign it. Sava Grujić reminded the King that by the agreement of December 1887, "which he had made with the radicals" the enactment of this law was included. To that, King Milan replied: "Well, sue me for the failure to complete the contract!" In such a situation, Grujić had no other option but to resign on April 26, 1888 (Jovanović 1990, 334-335). After submitting his resignation of the government, Sava Grujić wrote in a letter to the President of the Assembly "that he did it because the King did not want to give his sanction to the law on the organization of the municipality, as the Assembly voted with the consent of the government and did not receive corrections in the Law on army. The King also declared that he had broken the contract he had established with the radical party for calling it to the government" (Krstić 2007, 23).

\section{REFERENCES}

Dukić, Branko, Petar Maksimović. Politička načela, rukopisna zaostavština. Smederevo: Narodna biblioteka, 2008. Živanović, Živan, Politička istorija Srbije u drugoj polovini 19. veka, knj.4. Beograd: Geca Kon, 1924. Janković, Dragoslav, Rađanje parlamentarne demokratije. O političkim strankama u Srbiji 19. veka. Beograd: Pravni fakultet, 1997.

Jovanović, Slobodan, Vlada Milana Obrenovića, knj.2. Beograd: Bigz, 1990.

Kazimirović, Vasa, Nikola Pašić i njegovo doba (1845-1926), knj.1. Beogrard: Nova Evropa, 1990.

Kovačević, Duško, Srbija i Rusija 1878-1889. Beograd: Istorijski institut, 2003.

Ljušić, Radoš, Vlade Srbije (1805-2005). Beograd: Zavod za udzbenike i nastavna sredstva, 2005.

Mitrović, Jeremija, Nikola Pašić o osnovnim pitanjima unutrašnje i spoljne politike Srbije posle Slivnice, Istorijski glasnik, br.1. Beograd: Savez društva istoričara Srbije, 1971.

Mitrinović, Čedomil, Brašić, Miloš, Jugoslovenske Narodne skupštine i Sabori. Beograd: Narodna skupština Kraljevine Srbije, 1937.

Pešić, Miroslav, Političke stranke i uvođenje parlamentarizma u Srbiji od 1881-1903. Niš: Filozofski fakultet, 2017.

Protić, Stojan, Odlomci iz ustavne i narodne borbe u Srbiji, knj.2. Beograd: Dositej Obradović, 1912.

Radenić, Andrija, Radikalna stranka i Timočka buna, knj.2.Zaječar: Istorijski arhiv Timočka krajina, 1988.

Stojičić, Slobodanka, Ustavni razvitak Srbije 1868-1888. godine.Leskovac: Narodni muzej, 1980.

\section{UNPUBLISHED REFERENCE MATERIALS}

Serbian Archive, National Assembly Fund (AS, NS, f6-348/88)

Rista Odanić's personal collection (AS, RO, k. VI, no. 67).

Serbian Academy of science and art's Archive, no. 9327, Diary of Milan Đ. Milićević, 27 ${ }^{\text {th }}$ July 1887, book XIII).

Jovan Ristić's personal collection (ASANU, JR, IV/3, no. 33-34)

\footnotetext{
${ }^{5}$ In his Diary, Milan Piroćanac wrote that "the king appears impatient to free radicals and therefore he will be forced to wave over time and create new difficulties for himself. /.../ The Radical Cabinet has humiliated the authority of state authorities, which is almost unaware in the country, and has not improved its finances. Serbia stands before the bankruptcy because the radicals taught the people not to pay the debts "(Piroćanac 2005, 417).
} 


\section{PUBLISHED REFERENCE MATERIALS}

Krstić, Nikola, Dnevnik. Javni život, knj.4. Beograd: Zavod za udzbenike, 2007.

Milošević, Raša, Timočka buna.Uspomene. Beograd: Štamparija Drag. Gregorića, 1923.

Nikola P. Pašić, Pisma, članci i govori (1872-1891), priredili Latinka perović, Andrej Šemjakin, Beograd: Službeni list SRJ, 1995.

Piroćanac, Milan, Beleške, priredila Suzana Rajić, Beograd: Zavod za udzbenike, 2005.

Programi $i$ statutti srpskih političkih stranaka do 1918. godine, priredili Vasilije Krestić, Radoš Ljušić, Beograd: Književne novine, 1991.

Stenografske beleške Narodne skuoštine za 1887. godinu, Beograd 1888. godine

Todorović, Pera, Pisma ličnosti i ličnost, priredila Latinka Perović. Beograd: Službeni list Srbije, 2000

\section{NEWSPAPERS AND JOURNALS}

Srpske novine, Odjek, Radikal

\section{PRVA KOALICIONA LIBERALNO-RADIKALSKA VLADA U KRALJEVINI SRBIJI IZ 1887. GODINE}

U radu se govori o liberalno-radikalskoj vladi u Kraljevini Srbiji iz 1887. godine. Ovo je bila prva koaliciona vlada u istoriji novovekovne srpske države, koja je bila sastavljena od liberala $i$ radikala. Da bi došli na vlast radikali su pristali na manje aktuelne resore, dok su ministarstva spoljnih i unutrašnjih poslova pripala liberalima. Najvažnije tačke programa vlade, koji je bio odraz obostranog kompromisa, ticale su se poboljšanja odnosa sa Rusijom u spoljnoj i promene Ustava u unutrašnoj politici.

Ključne reči: Jovan Ristić, Narodna Skupština, Vlada, liberali, Ustav, radikali. 